\title{
A GUIDED INQUIRY INTO A DUBIOUS, PERVASIVE, ALL-AMERICAN ORGANIZATION: THE KU KLUX KLAN
}

John Holden Bickford

Eastern Illinois University

Jeremiah Clabough

University of Alabama at Birmingham

In many ways, America has embraced diversity in the $21^{\text {st }}$ century, which is evidenced by Barack Obama's election as the first African American President. Yet, gains for marginalized groups, coupled with an era of economic uncertainties, have created fertile fields for what may be a reemergence of America's dubious, most pervasive hate organization, the Ku Klux Klan. The Klan has historically emerged in three distinct waves as a reactionary response to political, cultural, and economic gains by marginalized groups. The August 2017 Unite the Right rally events in Charlottesville, Virginia prove, among other things, the $\mathrm{Ku}$ Klux Klan's modern presence in America and suggest a fourth manifestation of the Klan.

We offer a guided inquiry into America's dubious, most pervasive hate organization based on the central question: How has hate appeared and changed in America? To answer this question, students explore and extrapolate meaning from evocative primary sources that curiously juxtapose with a succinct secondary source. Students are positioned to articulate newly constructed understandings within diverse, text-based writing activities. The reading, thinking, and writing tasks all align with current educational initiatives and best practices in history education pedagogy. In this article, we first provide a rationale for this approach. Next, we offer an overview of white hegemony in the United States as it relates to the history of the Klan. Then,

(C) 2020 Bickford \& Clabough. Free to copy and share for education and scholarship under a Creative Commons Attribution NonCommercial-NoDerivatives 4.0 License. 
we provide specific sources and writing prompts teachers at the high school and university level can use to engage students in historical inquiry. Finally, because robust historical inquiry best prompts citizens' engagement, we suggest other timely topics for discussion with students.

\section{History Education Pedagogy}

History is a construction assembled from diverse sources. Historical artifacts are all potentially insightful, yet all are incomplete in different ways. Instructors can position students to recognize and consider positive and problematic elements, the meaningful details and the blind spots, within diverse sources.

\section{Diverse Sources}

Photographs present a seemingly clear window into the past; they convey a false sense of transparency and impartiality. ${ }^{1}$ Students, unless directed otherwise, may not scrutinize a photograph's minutiae for meaning. The photographer's influence on a published photograph is profound. Background, foreground, camera angle, subjects' facial features, title, and description are just a few aspects that shape how a photograph is viewed. Artistic renderings, never extemporaneous, are similarly complicated as the creator's figurative fingerprints appear throughout. Visual

\footnotetext{
1 Keith C. Barton and Linda S. Levstik, "Why Don't More History Teachers Engage Students in Interpretation?” Social Education 67, no. 6 (2003): 358-361; John Bickford, Molly Bickford, and Cynthia Rich, "Historical Literacy and Visual Informational Texts: Scrutinizing Photographs Beyond Their Borders," The Councilor: A Journal of the Social Studies 76, no. 2 (2015): 1-17; Cory Callahan, "Analyzing Historical Photographs to Promote Civic Competence," Social Studies Research and Practice 8, no. 1 (2013): 77-88; Stuart J. Foster, John D. Hoge, and Richard H. Rosch, "Thinking Aloud about History: Children's and Adolescents' Responses to Historical Photographs," Theory and Research in Social Education 27, no. 2 (1999): 179-214; National Association for Media Literacy Education, "Media Literacy Education and the Common Core State Standards," NAMLE, https:// namle.net/publications/mle-common-core-standards/; Bill Tally and Lauren B. Goldenberg, "Fostering Historical Thinking with Digitized Primary Sources," Journal of Research on Technology in Education 38, no. 1 (2005): 1-21.
} 
primary sources are engaging and accessible for learners.

Text-based primary sources, such as transcribed speeches, are perhaps less accessible but possibly richer than visual artifacts. They are arguably less accessible because textual decoding is potentially more complicated than visual decoding. Students, if not trained, read to comprehend and do not inherently read the silences. ${ }^{2}$ They should consider what was said, but also what was left unsaid, what might have prompted the text, and the possible response to the text. The author's influence is more apparent than the audience, the context, and the mode of delivery, but all should be considered. ${ }^{3}$ Textual primary sources abound with meaning, yet are complicated.

Primary sources, both visual and textual, offer insights into the past. Secondary sources were created long after the era by experts using the best available evidence. Yet not all evidence is available, perhaps not all was considered, and historians' narratives are also shaped by context and perspective. Secondary sources, especially textbooks which present a false sense of objectivity and breadth, are unnecessarily trusted by students. ${ }^{4}$ If given diverse sources with divergent perspectives, students can scrutinize, extract meaning, and organize their understandings using disciplinespecific cognitive tasks.

2 Jeffery Nokes, "Recognizing and Addressing the Barriers to Adolescents' 'Reading Like Historians,'” The History Teacher 44, no. 3 (2011): 379-404; Jeffery Nokes, Building Students' Historical Literacies: Learning to Read and Reason with Historical Texts and Evidence (New York, NY: Routledge, 2013); Sam Wineburg, Historical Thinking and Other Unnatural Acts: Charting the Future of Teaching the Past (Philadelphia, PA: Temple University Press, 2001).

3 Nokes, "Recognizing and Addressing the Barriers"; Nokes, Building Students' Historical Literacies; Wineburg, Historical Thinking and Other Unnatural Acts. 4 James W. Loewen, Lies My Teacher Told Me: Everything Your American History Textbook Got Wrong (New York, NY: Simon and Schuster, 2007); Wineburg, Historical Thinking and Other Unnatural Acts. 
Historical Reading, Thinking, and Writing

Students can engage in history literacy, historical thinking, and historical argumentation. ${ }^{5}$ History literacy, implied above, is the scrutiny of text and subtext to uncover a historical artifact's source, audience, context, limitations, and if claims can be corroborated. History literacy informs historical thinking, which manifests as students explore for cause and consequence, investigate tensions between change and resistance to change, consider various perspectives, and determine historical significance. History literacy and historical thinking shape historical argumentation, which is the evidence-based communication of newly constructed understandings. Historical argumentation often appears as written or spoken persuasive or evidentiary communications.

History literacy, historical thinking, and historical argumentation are separate stages that incrementally guide students towards higher tiers of criticality. ${ }^{6}$ Reduced to their

5 Chauncey Monte-Sano, Susan De La Paz, and Mark Felton, Reading, Thinking, and Writing About History: Teaching Argument Writing to Diverse Learners in the Common Core Classroom, Grades 6-12 (New York, NY: Teachers College Press, 2014); Bruce A. Lesh, “Why Won't You Just Tell Us the Answer?”: Teaching Historical Thinking in Grades 7-12 (Portsmouth, NH: Stenhouse, 2010); Nokes, Building Students' Historical Literacies; Peter Seixas and Tom Morton, The Big Six Historical Thinking Concepts (Toronto, Ontario: Nelson College Indigenous, 2012); Bruce A. VanSledright, Assessing Historical Thinking and Understanding: Innovative Designs for New Standards (New York, NY: Routledge, 2014); Sam Wineburg, Daisy Martin, and Chauncey Monte-Sano, Reading Like a Historian: Teaching Literacy in Middle and High School Classrooms (New York, NY: Teachers College Press, 2011).

6 Lorin W. Anderson and David R. Krathwohl, eds., A Taxonomy for Learning, Teaching, and Assessing: A Revision of Bloom's Taxonomy of Educational Objectives (New York, NY: Longman, 2001); Victor A. Benassi, Catherine Overson, and Christopher Hakala, eds., Applying Science of Learning in Education: Infusing Psychological Science into the Curriculum (Washington, D.C.: American Psychological Association, 2014); Lesh, “Why Won't You Just Tell Us the Answer?”; Nokes, "Recognizing and Addressing the Barriers"; Monte-Sano, De La Paz, and Felton, Reading, Thinking, and Writing About History; Seixas and Morton, The Big Six; VanSledright, Assessing Historical Thinking; Wineburg, Historical Thinking 
simplest form, history literacy, historical thinking, and historical argumentation are, respectively, reading, thinking, and communicating. When considered as cognitive tasks, they are analysis, evaluation, and creation, respectively. These elements of historical inquiry manifest within state and national education initiatives. $^{7}$

Teachers and professors can spark and scaffold students' history literacy, historical thinking, and historical argumentation. Reading prompts, if properly organized, can guide students to analyze unconsidered aspects, make intertextual connections they might not have seen, and assemble understandings they might not have made. A carefully constructed graphic organizer can act like a figurative ladder; complex tasks are condensed into small, manageable steps, each of which advances students' thinking upwards. We integrated history literacy and historical thinking tasks to spark and scaffold students' close reading and critical thinking, which form the basis for historical argumentation.

and Other Unnatural Acts; Wineburg, Martin, and Monte-Sano, Reading Like a Historian.

7 National Council for History Education, History's Habits of Mind, https:// www.nche.net/habitsofmind; National Council for the Social Studies, College, Career, and Civic Life (C3) Framework for Social Studies State Standards: Guidance for Enhancing the Rigor of K-12 Civics, Economics, Geography, and History (Silver Spring, MD: National Council for the Social Studies, 2013); National Governors Association Center for Best Practices \& Council of Chief State School Officers, Common Core State Standards for English Language Arts and Literacy in History/ Social Studies, Science, and Technical Subjects (Washington, D.C.: National Governors Association Center for Best Practice \& Council of Chief State School Officers, 2010). 
Table 1: Primary Source Analysis Guide

\begin{tabular}{|l|l|l|l|}
\hline Source \# & $\begin{array}{l}\text { Author and } \\
\text { Audience. List } \\
\text { everything known } \\
\text { about this author } \\
\text { and the audience. } \\
\text { Why was this } \\
\text { source created? } \\
\text { How would the } \\
\text { intended audience } \\
\text { respond? }\end{array}$ & $\begin{array}{l}\text { Context and } \\
\text { Significance. } \\
\text { When and where } \\
\text { was this source } \\
\text { created? Was this } \\
\text { created for public } \\
\text { or private viewing? } \\
\text { Why is this source } \\
\text { important? }\end{array}$ & $\begin{array}{l}\text { Corroboration } \\
\text { and Limitations. } \\
\text { How is this source } \\
\text { connected to, } \\
\text { similar to, or } \\
\text { other sources? } \\
\text { What cannot be } \\
\text { known from this } \\
\text { source? }\end{array}$ \\
\hline & & & \\
\hline & & & \\
\hline
\end{tabular}

Analysis of a single primary source develops into synthesis of understandings generated from previously-analyzed, related primary sources. Close reading prompts enable students to map convergences and divergences among various sources that originate at distinctly different times by folks with disparate aims. Students can trace the continuity and change within the Klan's intents, targets, and tactics within each particular emergence.

The questions in Table 1 are wide in scope to apply to a myriad of sources and facilitate discipline-specific cognition through practice. Instructors can also pose specific questions such as: How do you know if the artist was sympathetic to or critical of the Klan? How and why did the Klan's words position White, Christian, Americans as victims? How is the photographer or speaker trying to persuade you? Considering historical artifacts are incomplete, what is the most important information that you do not know? In other words, what is beyond the borders of or concealed within the photograph? Or, what did the speaker leave unspoken? Whether wide or narrow in scope, such questions steer students towards shrouded details and screened interconnections. As 
evaluation of diverse and divergent sources can easily overwhelm, instructors should be mindful of students' responses. Frustration can be eased with timely shifts between individual close reading, paired collaboration, and large group discussion. The above graphic organizer breaks history literacy and historical thinking into small steps as students read the historical sources. Prior to selecting the most appropriate sources, instructors must carefully consider the historiography.

\section{White Hegemony in America and the Ku Klux Klan}

Chattel slavery, vital to the social, cultural, economic, and political fabric of colonial America, institutionalized racism throughout colonial and antebellum America. In postbellum America, White segregationists maintained their economic, cultural, and political power on local, state, and national levels to suppress African Americans' civil liberties. ${ }^{8}$ As Henry Louis Gates convincingly argued, the American South developed and implemented Jim Crow segregation laws, which spread throughout the country, to maintain African Americans' secondclass status and ensure White supremacy. ${ }^{9}$ De jure laws, illustrated by the seminal Supreme Court case, Plessy v. Ferguson, and de facto practices enforced social segregation. ${ }^{10}$

African Americans and other marginalized groups were intentionally disenfranchised through poll taxes and literacy

\footnotetext{
8 Allen C. Guelzo, Fateful Lightning: A New History of the Civil War and Reconstruction (New York, NY: Oxford University Press, 2012); Morton Keller, America's Three Regimes: A New Political History (New York, NY: Oxford University Press, 2007); Rayford W. Logan, The Betrayal of the Negro, from Rutherford B. Hayes to Woodrow Wilson (New York, NY: Collier Books, 1965). 9 Henry Louis Gates, Jr., Stony the Road: Reconstruction, White Supremacy, and the Rise of Jim Crow (New York, NY: Penguin Press, 2019).

10 Robert L. Allen, The Port Chicago Mutiny (Berkeley, CA: Heyday, 2006), 28-37; Harvey Fireside, Separate and Unequal: Homer Plessy and the Supreme Court Decision that Legalized Racism (New York, NY: Carroll \& Graf, 2005); Charles A. Lofgren, The Plessy Case: A Legal-Historical Interpretation (New York, NY: Oxford University Press, 1987).
} 
tests. Poll taxes, in which a citizen must pay to vote, compelled the poor to choose between living expenses and civic contributions. Literacy tests, with capricious content, arbitrarily targeted African Americans, who had little access to schooling. Poll taxes and literacy tests, supplemented with violence and threats of violence, contributed to political segregation. ${ }^{11}$ Justice has not been blind, as the Emmitt Till case, Scottsboro Boys case, and Birmingham's convict-leasing system are a small sampling from a full harvest. ${ }^{12}$ Nothing represents White hegemony as viscerally, though, as the $\mathrm{Ku}$ Klux Klan.

The KKK is a traditionally secretive, White supremacist organization with an undetermined membership. ${ }^{13}$ The Klan's

11 Michael Ezra, The Economic Civil Rights Movement: African Americans and the Struggle for Economic Power (New York, NY: Routledge Press, 2013); Elaine F. Parsons, Ku-Klux: The Birth of the Klan during Reconstruction (Chapel Hill, NC: University of North Carolina Press, 2016).

12 Douglas A. Blackmon, Slavery by Another Name: The Re-enslavement of Black Americans from the Civil War to World War II (New York, NY: Doubleday, 2008); Matthew J. Mancini, One Dies, Get Another: Convict Leasing in the American South, 1866-1928 (Columbia, SC: The University of South Carolina Press, 1996). 13 Charles C. Alexander, The Ku Klux Klan in the Southwest (Lexington, KY: University of Kentucky Press, 1965); Kelly J. Baker, Gospel According to the Klan: The KKK's Appeal to Protestant America, 1915-1930 (Lawrence, KS: University Press of Kansas, 2011); David Cunningham, Klansville, U.S.A.: The Rise and Fall of the Civil Rights-Era Ku Klux Klan (New York, NY: Oxford University Press, 2013); Linda Gordon, The Second Coming of the KKK: The Ku Klux Klan of the 1920s and the American Political Tradition (New York, NY: Liveright Publishing Corporation, 2017); Kenneth T. Jackson, The Ku Klux Klan in the City, 1915-1930 (New York, NY: Oxford University Press, 1967); Shawn Lay, The Invisible Empire in the West: Toward a New Historical Appraisal of the Ku Klux Klan of the 1920s (Urbana, IL: University of Illinois Press, 1992); Rory McVeigh, The Rise of the Ku Klux Klan: Right-Wing Movements and National Politics (Minneapolis, MN: University of Minnesota Press, 2009); Michael Newton, The FBI and the KKK: A Critical History (Jefferson, NC: McFarland \& Co., 2005); Michael Newton, The Ku Klux Klan: History, Organization, Language, Influence, and Activities of America's Most Notorious Secret Society (Jefferson, NC: McFarland \& Co., 2006); C. Vann Woodward, Origins of the New South, 1877-1913: A History of the South (Baton Rouge, LA: Louisiana State University Press, 1951), 1-23; C. Vann Woodward, Reunion and Reaction: The Compromise of 1877 and the End of Reconstruction 
figurative fire of White supremacy burns from many logs, which include racism, xenophobia, anti-Semitism, anti-Catholicism, and Islamophobia. The KKK has had three surges, each of which centered on intimidation and violence.

The Ku-Klux, as it was first called, originated in the former Confederacy and border states soon after the U.S. Civil War. ${ }^{14}$ During Reconstruction, the Ku-Klux opposed Northern occupation and Republican influence. As federal, Northern, and Republican intervention retracted, the Ku-Klux worked to restrict African Americans' newly earned civil liberties, social mobility, and economic advances. During this period, Ku-Klux members wore distinct robes and identity-concealing masks as they burned buildings and lynched ex-slaves and their advocates.

The second surge appeared after D. W. Griffith romanticized the Klan's origins in The Birth of a Nation. ${ }^{15}$ It lasted for more than a decade after what was then called the Great War. During this Second Wave, the Ku Klux Klan expanded into Midwestern and Western rural and urban areas. Protestantism and regional economic uncertainties rooted in a post-War recession shaped this surge. KKK adherents wore white robes, but often went unmasked to create a public narrative of political decency and social legitimacy. Cross burnings, seeking public office, and mass parades, particularly in large cities, illustrate the conspicuous nature of the Klan's Second Wave.

The Ku Klux Klan's third surge manifested during the modern Civil Rights Movement of the 1950s and 60s. The Klan's Third

(Boston, MA: Little, Brown \& Company, 1966).

14 Parsons, Ku-Klux: The Birth of the Klan; C. Vann Woodward, The Strange Career of Jim Crow (New York, NY: Oxford University Press, 1955); Woodward, Origins of the New South; Woodward, Reunion and Reaction.

15 Alexander, The Ku Klux Klan in the Southwest; Baker, Gospel According to the Klan; Gordon, The Second Coming of the KKK; Robert M. Fogelson and Richard E. Rubenstein, eds., Hearings on the Ku Klux Klan, 1921 (New York, NY: Arno Press, 1969); Stetson Kennedy, The Klan Unmasked (Boca Raton, FL: Florida Atlantic University Press, 1954). 
Wave was a reactionary response to the social, economic, and political changes advocated for by African American citizens, legislated by Congress, and enacted by state and federal courts. ${ }^{16}$ The KKK's Third Wave was less public than the second, emerged throughout the country's rural and urban areas, and utilized arson and murder to terrorize. The Federal Bureau of Investigation monitored, regulated, and, at times, augmented the Klan's sway during this Third Wave. ${ }^{17}$ Cross burnings, demonstrations, and acts of violence, not parades, best exemplify this Third Wave.

The Ku Klux Klan has materialized, withdrawn, and reemerged to oppose integration, immigration, non-Protestant faiths, and minority groups' use of civil liberties during times when minority groups make social, political, and economic gains. The KKK has historically been America's most prominent hate group, yet other organizations have materialized. The intents, targets, tactics, and memberships of these groups are, at times, comparable to the Klan. The Citizens' Council, American Nazi Party, and Identity Evropa are but three examples. The Citizens' Council-sometimes termed White Citizens' Council, Citizens' Councils of America, or Council of Conservative Citizenshas used economic coercion (e.g., arbitrary firing, coordinated boycotts), voter suppression and intimidation, and, at times, violence to achieve similar means to the Klan. ${ }^{18}$ The American Nazi Party, more shrouded than Citizens' Councils, responds to events with terror and threats. ${ }^{19}$ Identity Evropa, which emerged from the splintered American Nazi Party, has recently

16 Cunningham, Klansville, U.S.A.; Newton, The Ku Klux Klan.

17 Newton, The FBI and the KKK.

18 Neil R. McMillen, The Citizens' Council: Organized Resistance to the Second Reconstruction (Urbana, IL: University of Illinois Press, 1994); Gene Roberts and Hank Klibanoff, The Race Beat: The Press, the Civil Rights Struggle, and the Awakening of a Nation (New York, NY: Alfred A. Knopf, 2006).

19 Christopher Harmon, Terrorism Today (New York, NY: Taylor and Francis, 2007); William H. Schmaltz, Hate: George Lincoln Rockwell and the American Nazi Party (Washington, D.C.: Brassey, 1999). 
emerged on college and university campuses and at urban rallies resisting immigration, globalism, and any diminishment-real or perceived-of White hegemony. Racial violence and intimidation persist at the time of this writing as hate crimes have increased in frequency. ${ }^{20}$ While the Klan remains visible and threatening in the $21^{\text {st }}$ century, ${ }^{21}$ these and other groups oppose immigration, integration, and non-Protestant faiths, as the Klan had in the past, but also globalism and LGBTQ rights. The self-titled Unite the Right rally illustrates this amalgamation of White nationalism that may be judged by future generations as the KKK's fourth insurgency. ${ }^{22}$ This guided inquiry into the Klan's history, which is intended for use by high school teachers and college professors, relies on evocative history-based sources.

\section{KKK-Based Historical Sources}

Teachers and professors may want to ground the historical inquiry with a secondary source. Susan Campbell Bartoletti's They Called Themselves the K.K.K.: The Birth of an American Terrorist Group is accessible and rich with detail. ${ }^{23}$ Instructors,

20 Federal Bureau of Investigation, "Hate Crime Data (Uniform Crime Reporting Program)," Federal Bureau of Investigation, https://ucr.fbi. gov/hate-crime; Southern Poverty Law Center, "Hate Crimes Explained," Southern Poverty Law Center, https:/www.splcenter.org/20180415/ hate-crimes-explained.

21 Hawes Spencer and Matt Stevens, "23 Arrested and Tear Gas Deployed After a K.K.K. Rally in Virginia," New York Times, July 8, 2017, https:// www.nytimes.com/2017/07/08/us/kkk-rally-charlottesville-robert-e-leestatue.html? $\mathrm{r}=0$.

22 Hawes Spencer and Sheryl Gay Stolberg, "White Nationalists March on University of Virginia," New York Times, August 11, 2017, A12, https://www. nytimes.com/2017/08/11/us/white-nationalists-rally-charlottesville-virginia. html? searchResultPosition=3; Meg Wagner, “Blood and Soil': Protestors Chant Nazi Slogan in Charlottesville," CNN, August 12, 2017, https://www. cnn.com/2017/08/12/us/charlottesville-unite-the-right-rally/index.html. 23 Susan Campbell Bartoletti, They Called Themselves the K.K.K: The Birth of an American Terrorist Group (New York, NY: Houghton Mifflin, 2010). 
though, may want a more succinct secondary source. A careful reading of Bartoletti's trade book or a summary drawn from the latest research, such as that in Figure 1, provides necessary background on the Klan. Students, then, are better prepared to explore primary sources illustrating the KKK's three waves.

The Ku Klux Klan is a traditionally secretive, White supremacist organization with an undetermined membership; it has contributed mightily to America's White supremacy over the last century and a half. The Klan's White supremacy targets anyone who is not white, American, of the Protestant branch of Christianity, and heterosexual. They are racist, xenophobic, anti-Semitic, anti-Catholic, and Islamophobic. The KKK has had historically three surges, each of which center on intimidation and violence.

The Klan originated in the former Confederacy and border states soon after the U.S. Civil War. During this First Wave, they often went by just Ku Klux (only sometimes was "Ku Klux Klan" used...). During Reconstruction, the Klan opposed Northern occupation and Republican influence and supported the Democratic Party. As federal, Northern, and Republican intervention withdrew from the South, the Klan worked to restrict African Americans' newly-earned civil liberties (like voting), social mobility (like living in nice neighborhoods), and economic advances (like getting better jobs). During this period, Klan members wore distinct robes and masks-but not always the white gowns and cloaks-as they burned buildings and lynched ex-slaves and their people who helped African Americans.

The second surge appeared after D. W. Griffith's movie The Birth of a Nation in $1915 .{ }^{24}$ In it, Griffith made the Klan's origins seem almost heavenly, inspired by God, and something that helped make America a good place. This Second Wave lasted for a decade after World War I (what was then called The Great War). During this wave, the KKK expanded into Midwestern and Western rural and urban areas while supporting the Democratic Party. Unlike during the First Wave, this Second Wave expanded from racism against African Americans into

24 David Wark Griffith, The Birth of a Nation, Directed by David Wark Griffith (1915, United States: Epoch Producing Company, 1915), Film. 
anti-Semitism and anti-Catholicism. Protestantism shaped this surge. KKK members wore white robes during parades, sometimes with and other times without masks. Sometimes, they wore masks to scare and intimidate. Other times, they went unmasked to appear like decent regular folks. Cross burnings and mass parades, particularly in large cities, were a big part this wave.

The Klan's third surge emerged during the Civil Rights Movement of the 1950s and 1960s. It was a response to the changes made by African American citizens (think: Rosa Parks and Dr. King), legislated by Congress (think: 1964 Civil Rights Act and 1965 Voting Rights Act), and decided by state and federal courts (think: Brown v. Board of Education). The Klan's Third Wave was less public than the Second Wave, emerged throughout the country's rural and urban areas, used arson and murder to terrorize, and shifted to the Republican Party due to the changing nature of the Democratic Party. The Federal Bureau of Investigation (FBI) monitored the KKK but, sadly, let them get away with things. Cross burnings, demonstrations, and acts of violence, not parades, exemplify this Third Wave.

The Klan has materialized, withdrawn, and reemerged to oppose integration, immigration, non-Protestant faiths, and minority groups' use of civil liberties. Historically, the Klan has done this during times when minority groups made social, political, and economic gains. The KKK has historically been America's most prominent hate group, yet other organizations have materialized. The intents, targets, tactics, and memberships of these groups are, at times, comparable to the Klan. The Citizens' Council (during boycotts of the 1950s) and American Nazi Party (during the 1960s) are two examples.

Figure 1: A Summary of the KKK condensed from the latest historical research.

\section{First Wave}

Frank Bellew's (1872) Visit of the Ku-Klux ${ }^{25}$ illustrates various elements of the First Wave of the Ku-Klux (Klan was added later). The wood engraving (Figure 2) depicts the Ku-Klux's violence

25 Bellew, Frank, Artist. Visit of the Ku-Klux / drawn by Frank Bellew, 1872.

Photograph. https://www.loc.gov/item/2001695506/. 
directed at African Americans during the Reconstruction era, though the nighttime raider was not dressed in the attire normally associated with the Ku-Klux. This terror was in response to African Americans' gains from the U.S. Civil War and the political foot established by Republicanism in Democratic strongholds of the South.

Students quickly determine that the artist positioned the $\mathrm{Ku}$ Klux member inconspicuously appearing at an African American family's home to shoot the family from behind with the rifle. The family members are simply going about their usual evening routines with no warning of the threat. A $21^{\text {st }}$ century viewer may question how no member of the freedman family could detect the Ku-Klux when the door is wide open; the instructor could ask students, "Must artists' representations be literal depictions? What does art provide that other extemporaneous documents do not?" This etching suggests the Ku-Klux rely on surprise, which heightens fear among the formerly enslaved people who do not know when or where the vigilantes might next appear. A modern audience may wonder why the Ku-Klux would attack late in the evening when children are present; as the Ku-Klux sought coercion through violence and intimidation, children's presence only boosted the success of the nighttime attack. The instructor should highlight the Ku-Klux member's appearance, who is not wearing the traditional white hood and robe with which Klan members are usually associated. Instead, he wore a sack presumably to hide his appearance at night, which reinforces the anonymity, terror, and surprise of his appearance. 


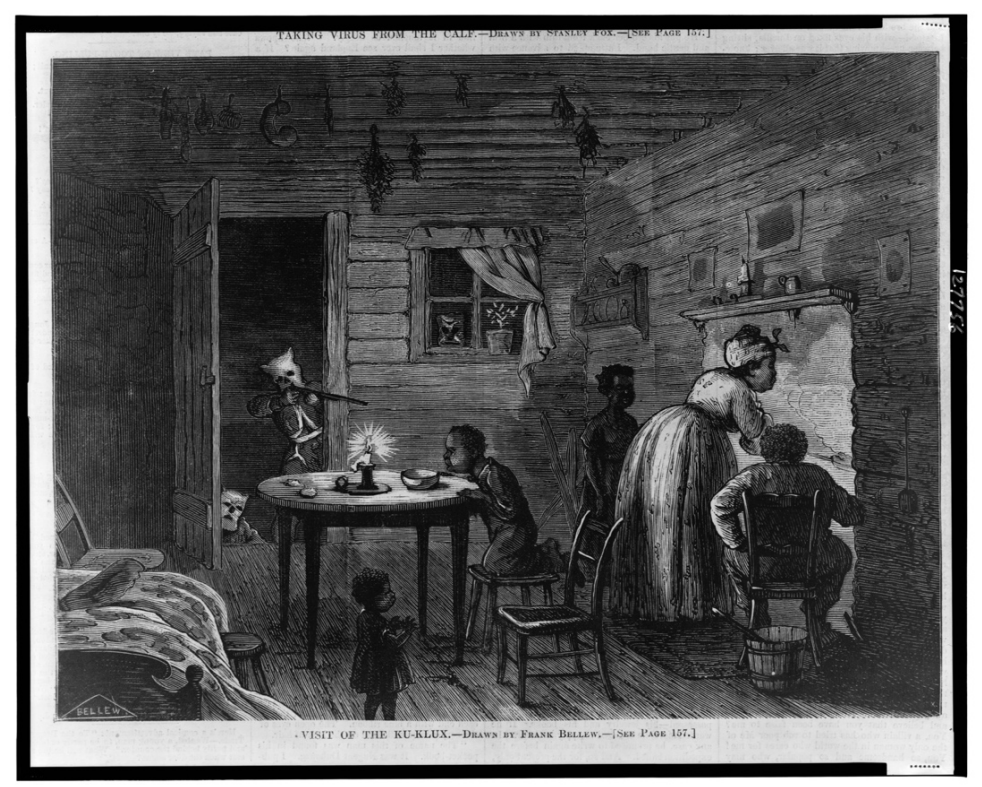

Figure 2: Visit of the Ku-Klux, 1872. ${ }^{26}$

Details extracted from the wood engraving can yield deeper meaning through inquiry. First, the artist, Frank Bellew, was of European descent and moved to and worked in New York. The source, thus, suggests Northern perceptions about Southern racial violence during Reconstruction. Second, the wood engraving lacks any reference to location. The viewer, thus, is left with the impression that this scene could happen anywhere in the South, which reflects the terror that African Americans faced on a daily basis from the Ku-Klux. Finally, the engraving is labeled KuKlux, not Ku Klux Klan, and is dated 1872. From the date and the shortened name, students easily establish this is the hate group's first iteration.

The 1872 drawing within Harper's Weekly (Figure 3)

26 Ibid. 
depicts three members of the Ku-Klux captured and arrested in Mississippi. ${ }^{27}$ The Ku-Klux's attire may immediately draw students' attention as it contrasts with their schema. Not wearing the white hood and white robes often associated with this group, their clothing is darker, presumably to not be noticeable at night, and their identities are concealed by a "white blanket or sheet" positioned as a mask. Details such as the name, attire, and date enable a viewer to identify these individuals as being part of this organization's first manifestation, which connects to Frank Bellew's wood engraving.

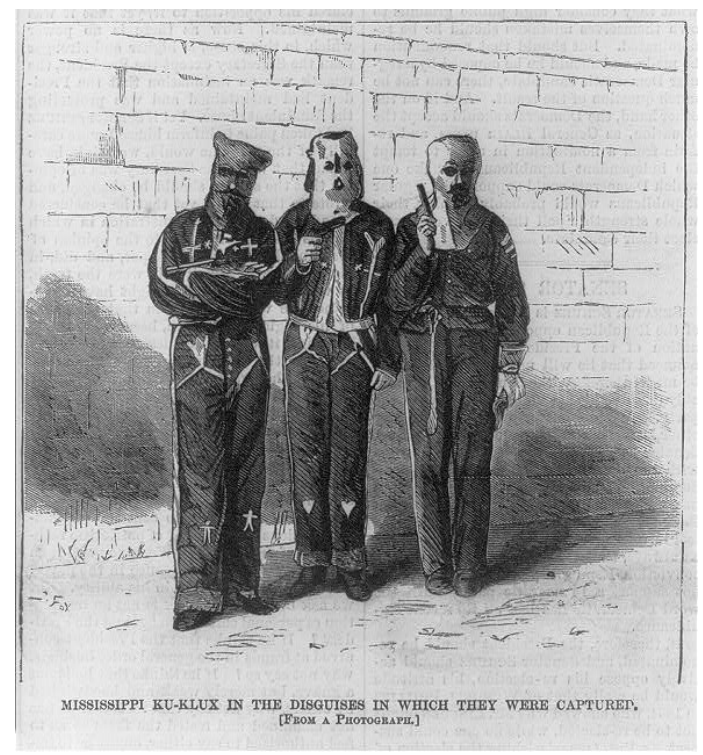

Figure 3: Mississippi Ku-Klux in the Disguises in which They were Captured, $1872 .{ }^{28}$

27 “The Ku-Klux," Harper's Magazine, January 27, 1872, https://babel.hathitrust. $\mathrm{org} / \mathrm{cgi} / \mathrm{pt}$ ?id=mdp.39015014703303\&view=1up\&seq=78.

28 Mississippi Ku-Klux in the Disguises in which They were Captured, 1872, photograph, Library of Congress, Washington, D.C., https://www.loc.gov/ item/2006687376/. 


\section{THE KU-KLUX}

We give you this page as illustration, engraved from a photograph from life, showing three members of a band of Mississippi Ku-Klux, who are now under indictment in that State for the attempted murder of a family... The illustration is doubly interesting as showing the disguises actually worn by these miscreants. They are not, however, always so elaborate in their brigand toilet. A white blanket or sheet thrown over the head with holes for the eyes is usually sufficient. ... Recent intelligence from Kentucky shows that the government can not be too prompt and energetic in its measures of protection. On the night of the $2 \mathrm{~d}$ inst. A band of twenty $\mathrm{Ku}$-Klux made a raid upon some negroes near Frankfort, in that State, whipping one of them and ordering the others to leave the neighborhood on pain of death. One farmer was warned to employ none but white laborers. It is the declared purpose of these outlaws to drive the negroes from the county. But the day is past when such threats can be carried out. These outlaws will speedily be taught that the government will protect peaceable citizens in the full enjoyment of their rights, life, and property, if it takes the whole military power of the nation to do it.

Figure 4: Mississippi Ku-Klux in the Disguises in which They were Captured, $1872 .^{29}$

The accompanying Harper's Weekly story (Figure 4) reports Klan-led turmoil. That these three Ku-Klux members were arrested distinguishes Harper's Weekly drawing and the accompanying story from Bellew's wood engraving. Readers can extract meaningful details from the brief excerpts about the Klan's intentional chaos ("A band of twenty Ku-Klux made a raid 
upon some negroes near Frankfort, in that State, whipping one of them and ordering the others to leave the neighborhood on pain of death"), the author's clear condemnation ("The illustration is doubly interesting as showing the disguises actually worn by these miscreants"), and the author's call for federal intervention ("These outlaws will speedily be taught that the government will protect peaceable citizens in the full enjoyment of their rights, life, and property, if it takes the whole military power of the nation to do it"). In these ways, students can make text-based conclusions about the significance, source, and context of the historical document. The understandings students will extract from the above drawing and accompanying story intersect curiously.

Abram Colby, an African American who went from enslaved worker to Georgia legislator, experienced the Klan's carnage. In 1872, Colby testified before a Congressional Committee about the violence that African Americans faced in the South. In the excerpts in Figure 5, Colby articulated his perceptions of the Klan's tactics and intent.

Colby: On the 29th of October 1869, [the Klansmen] broke my door open, took me out of bed, took me to the woods and whipped me three hours or more and left me for dead. They said to me, "Do you think you will ever vote another damned Radical ticket?" I said, "If there was an election tomorrow, I would vote the Radical ticket." They set in and whipped me a thousand licks more, with sticks and straps that had buckles on the ends of them

Question: What is the character of those men who were engaged in whipping you?

Colby: Some are first-class men in our town. One is a lawyer, one a doctor, and some are farmers. They had their pistols and they took me in my night-clothes and carried me from home. They hit me five thousand blows. I told President Grant the same that I tell you now. They told me to take off my shirt. I said, "I never do that for any man." My drawers fell down about my feet and they took hold of them and tripped me up. Then they pulled my shirt up over my head. They said I 
had voted for Grant and had carried the Negroes against them. About
two days before they whipped me they offered me $\$ 5,000$ to go with
them and said they would pay me $\$ 2,500$ in cash if I would let another
man go to the legislature in my place. I told them that I would not do
it if they would give me all the county was worth.
The worst thing was my mother, wife and daughter were in the
room when they came. My little daughter begged them not to carry
me away. They drew up a gun and actually frightened her to death. She
never got over it until she died. That was the part that grieves me the
most.
Question: How long before you recovered from the effects of this
treatment?
Colby: I have never got over it yet. They broke something inside of
me. I cannot do any work now, though I always made my living before
in the barber-shop, hauling wood, etc.
Question: You spoke about being elected to the next legislature?
Colby: Yes, sir, but they run me off during the election. They swore
they would kill me if I stayed. The Saturday night before the election I
went to church. When I got home they just peppered the house with
shot and bullets.

Figure 5: Account of Abram Colby, 1872.30

Readers quickly learn about the Klansmen's midnight home invasion to intimidate and attack Colby. He argued the Klansmen's methods were designed to silence African Americans' political engagement. The Ku-Klux sought to suppress Colby's vote to ensure its party's and candidates' success. An instructor might prompt students to consider the limitations of Colby's powerful, first-hand account with questions like: "What are the limitations of this primary source? What can Colby not know?" A teacher might also position students to corroborate Colby's claims

30 Dorothy Sterling, ed., The Trouble They Seen: The Story of Reconstruction in the Words of African Americans (Boston, MA: De Capo Press, 1994), 374-375. 
through intertextual connections: "How does Colby's testimony connect to ideas expressed by other sources?" or spark further inquiry: "If the vigilantes wanted to disenfranchise the recentlyenfranchised African Americans, which political party did the Ku-Klux support?" While not clearly stated, an exploration would alert students that Ku-Klux members supported the Democratic Party in this particular election and opposed President Ulysses S. Grant, a Republican and Northerner.

Colby's testimony illustrates African Americans' lived experiences when exercising their political rights as citizens. It explicitly connects in various ways with both Bellew's (1872) wood engraving and the Harper's Weekly (1872) story and accompanying image. Further inquiry reveals the KKK's political support of the Democratic Party.

\section{Second Wave}

The Klan expanded into the American Midwest and West starting around 1915 and lasting for more than a decade. This Second Wave is illustrated by iconic KKK attire and epitomized by the Klan's interest in social legitimacy and political recognition. In public, the KKK conspicuously sought acceptance; in private, they terrorized and burned crosses to symbolize the light of Jesus Christ through mayhem. They often wore the emblematic coned hoods and white gowns during parades, public demonstrations, and private ceremonies while donning the suits representative of business leaders when meeting elected officials. The white robes signified purity and the White race; the business suits connoted lawfulness and legitimacy. As in the First Wave, the Klan invoked racial purity and White, Protestant virtue into displays of normalcy and power. These elements appear in the selected sources representing the KKK's Second Wave.

Colonel William Joseph Simmons was a mobilizing force during the Klan's Second Wave. In 1922, Simmons testified about the Ku Klux Klan to the United States legislature. The House Committee investigated the Klan for accusations of violence. 
Testimonial excerpts and an accompanying photograph provide clues into the Klan's intent and performance.

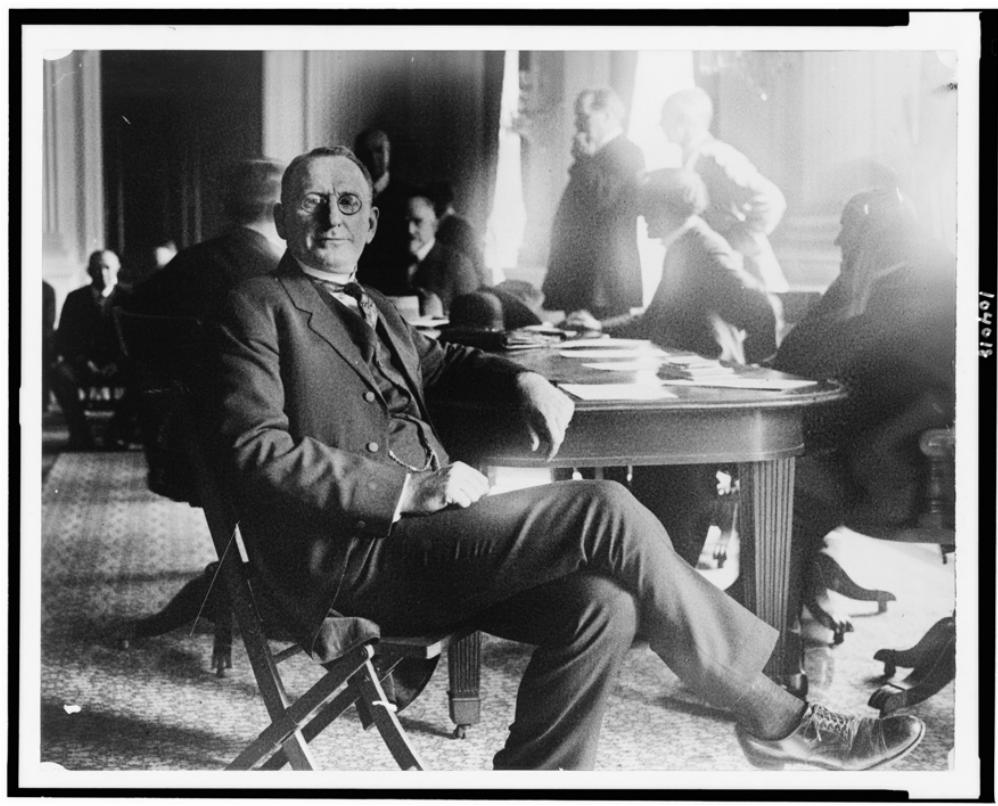

Figure 6: Col. William Joseph Simmons, Full-Length Portrait, Seated at Table During House Committee Investigation of the Ku Klux Klan, 1921. ${ }^{31}$

Colonel Simmons, in word and wardrobe, sought to present the Klan and its members as a legitimate, yet unfairly hounded social organization made up of sensible, law-abiding citizens. Students can be tasked with scrutinizing Simmons' posture, garb, and location in the photograph (Figure 6). Simmons appears calm and comfortable in posture; he seems dignified, almost genteel, and innocuous in apparel; and, seated at the head of the long table, he conveys the impression of being a trailblazing leader.

31 Col. William Joseph Simmons, Full-Length Portrait, Seated at Table During House Committee Investigation of the Ku Klux Klan; Men Standing and Seated in Background, 1921, photograph, Library of Congress, Washington, DC, https:// www.loc.gov/item/91792441/. 
Simmons' carefully crafted language (Figure 7) adds nuance to the image. Close reading tasks can prompt students to consider the logic and evidence grounding the assertions: "If the Knights of the Ku Klux Klan had been a lawless organization... it would have not shown the remarkable growth it has"; allusions: "I cannot better express myself than by saying to you who are persecutors of the Klan and myself, 'Father forgive you, for you know not what you do"'; and implications: "You are ignorant of the principles [of the Klan] as were those who were ignorant of the character and work of the Christ." Students, if given the task, can distinguish hyperbole from fact and separate evidence-based logic from casuistry in the excerpts. When juxtaposing the testimony and the photograph, students recognize that Simmons characterized the Klan as law-abiding, respectful, unfairly persecuted, White, Christian citizens. Without reticence, he projected normalcy in language and clothing.

"If the Knights of the Ku Klux Klan had been a lawless organization, as has been charged, it would have not shown the remarkable growth it has, for in the Klan is as fine a body of representative citizens as there is in the United States. In each community where there is a Klan will be found members from the leading citizens, men who stand at the forefront in their cities. These men would not stand for lawlessness."

"You are ignorant of the principles [of the Klan] as were those who were ignorant of the character and work of the Christ. I cannot better express myself than by saying to you who are persecutors of the Klan and myself, 'Father forgive you, for you know not what you do,' and 'Father forgive them for they know not what they do."'

Figure 7: Colonel William Joseph Simmons, testimony during Congressional Hearings, $1921 .^{32}$

32 Fogelson and Rubenstein, eds., Hearings, 69; 138. 
When students extrapolate meaning from photographs and the accompanying details, they are discovering, not simply digesting, key details. The sources in Figures 6 and 7 enable students to explore the Klan's carefully constructed, seemingly benign, daytime, public image. In Figures 8 and 9, the KKK's private, nighttime power is apparent.

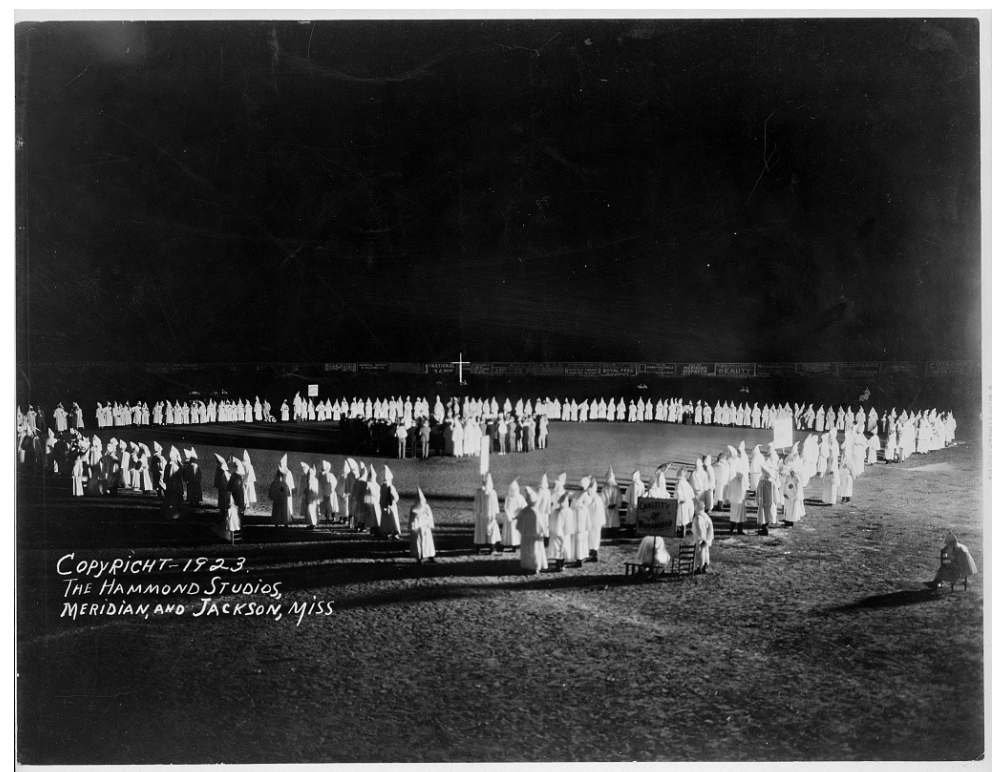

Figure 8: Ku Klux Klan initiation, $1923 .{ }^{33}$

33 Ku Klux Klan initiation - no. 2. Mississippi, ca. 1923. Aug.13. Photograph. https://www.loc.gov/item/2006679234/. 


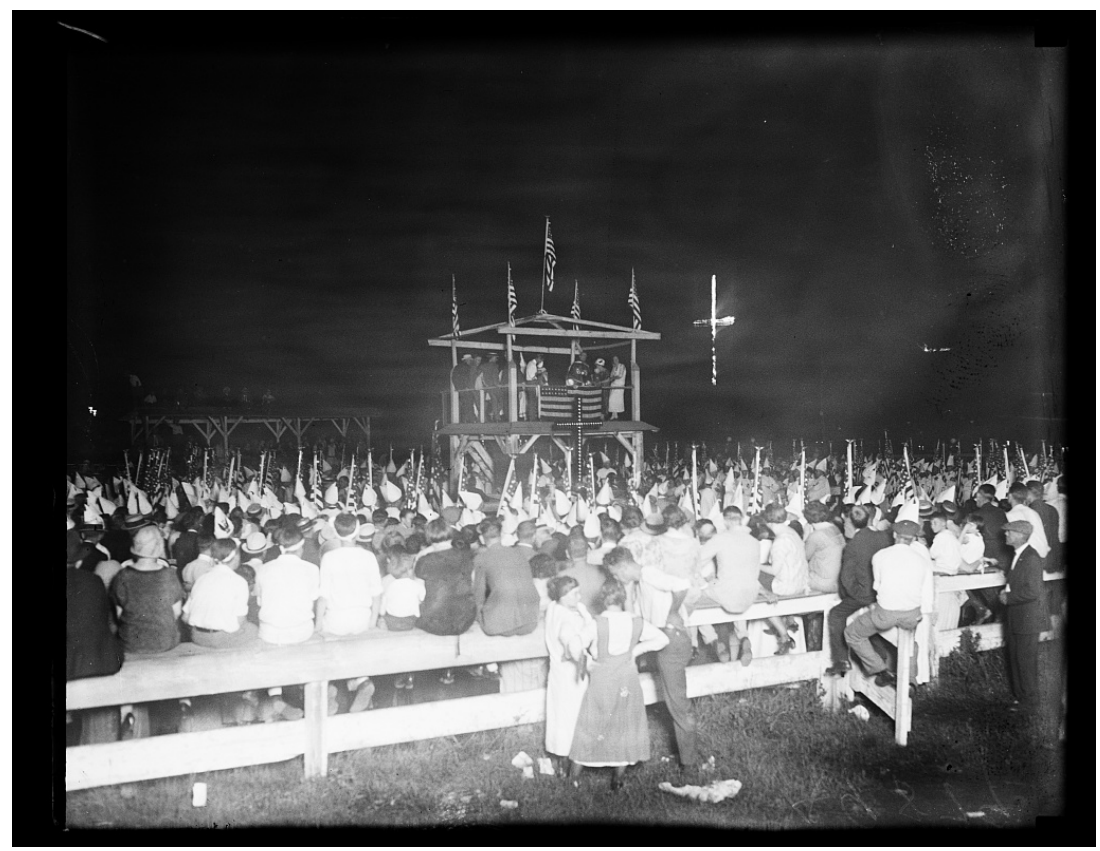

Figure 9: Cross burning, Ku Klux Klan, 1925. ${ }^{34}$

Curious aspects appear when reading Figures 8 and 9 in concert. The instructor could ask students, "What details, both similarities and differences, stand out?" Initial similarities would include nighttime rallies in large fields and likely white audiences standing in rapt attention. Closer inspection might reveal a burning cross and American flag in the background of both. Superficial differences might include what appears to be a lined football field on top and a fenced-in field at the bottom; the former is more likely a public place than the latter. Closer consideration of differences likely yields that the former seems to be a Klan-only nighttime rally while the latter appears to be open to the public. Other photographs might add depth to students'

34 Harris \& Ewing, photographer, Cross burning, Ku Klux Klan, United States, 1925, photograph, https://www.loc.gov/item/2016894342/. 
examination of the Klan's Second Wave, such as their presence far from the American South in Maine. ${ }^{35}$

The $\mathrm{Ku}$ Klux Klan's Second Wave exceeded five million dues-paying members and continued its ties to the Democratic Party. While exact numbers cannot be definitely ascertained, an estimated thirty-thousand followers marched in Washington, D.C. in August 1925, and a similar spectacle returned in September 1926. Two photographs from the second Washington parade (Figures 10 and 11) highlight the Klan's public positioning.

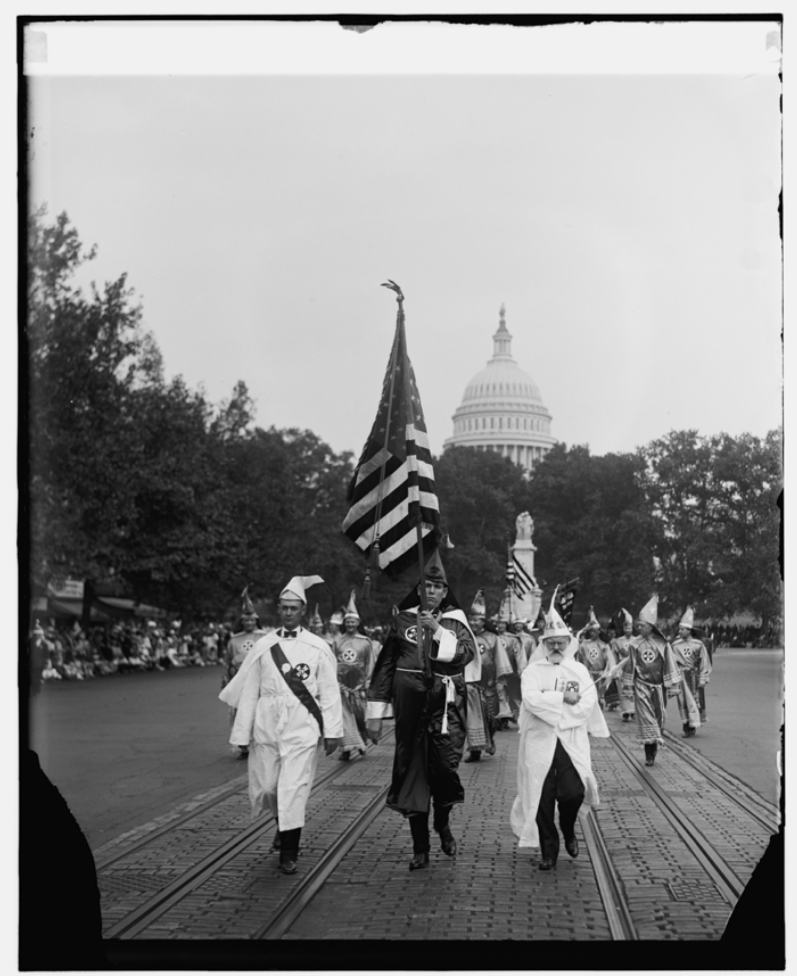

Figure 10: Ku Klux Klan Parade, Washington, D.C., 1926. ${ }^{36}$

35 Ku Klux Klan gathering at Portland, Maine on ca. 1923. December 31. Photograph. https://www.loc.gov/item/2016649428/.

36 Ku Klux Klan Parade, 9/13/26, 1926, photograph, Library of Congress, 


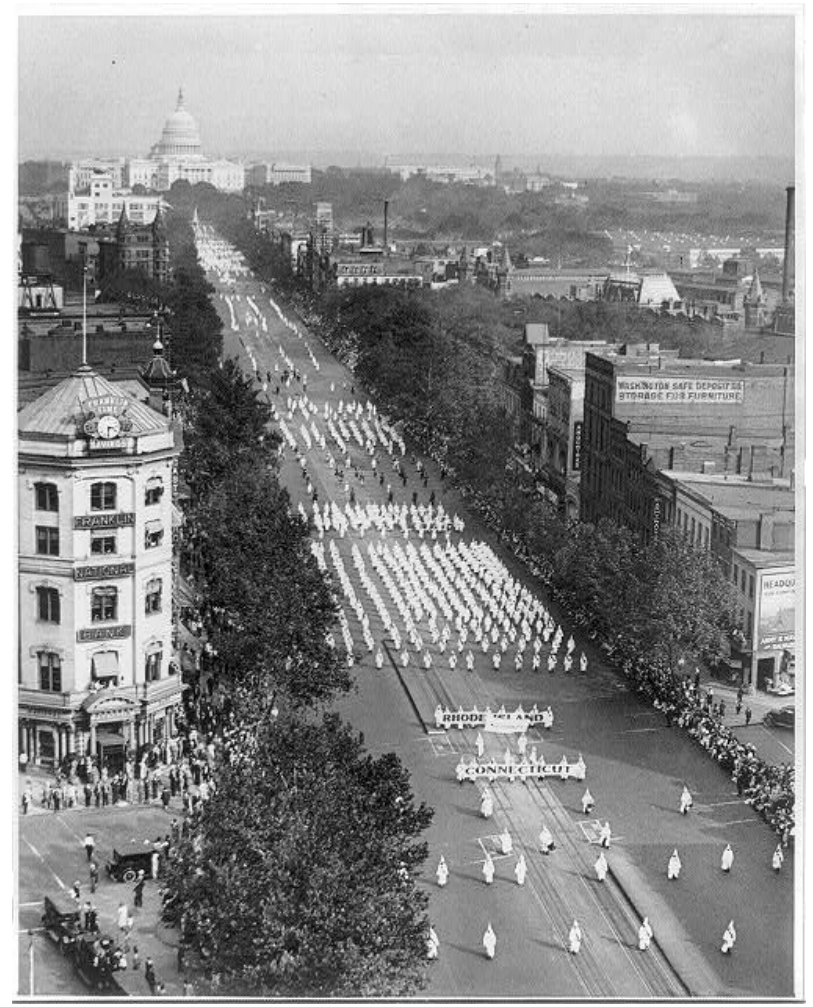

Figure 11: Ku Klux Klan Parade, Washington, D.C. on Pennsylvania Ave., 1926. ${ }^{37}$

Students can unearth important understandings from viewing both photographs. Students, if asked, can easily ascertain the intent and significance of the location of the mass demonstration. Seeking legitimacy from the American people, the KKK exhibited strength in numbers while stopping traffic and normal business at America's capital. A cursory review of the photographs, in which

Washington, D.C., https://www.loc.gov/item/2016842483/.

37 Ku Klux Klan Parade, Washington, D.C. on Pennsylvania Ave., 1926, photograph, Library of Congress, Washington, D.C., https://www.loc.gov/ item/2001706338/. 
the Capitol Dome is in the background, indicates the intended messages of patriotism and power. Symbolism of the Klan's patriotism emerges from the parade's location and path, which were both carefully selected. The marchers walked from the Capitol Dome, in which the Legislative branch works, towards the White House, in which the Executive branch resides. The Ku Klux Klan's path down Pennsylvania Avenue implies its soughtafter connection with the U.S. government. The KKK's power was revealed in the parade's immensity, which was vast. Scrutinizing both photographs reveals more. The marchers paraded down the streets of segregated Washington D.C., some hooded and some showing their face. The former communicates power through secrecy and the latter conveys intimidation through brazen exposure. When asked to consider African Americans' probable perspectives on the parade, students would first suggest shock at the spectacle and later would likely determine that few Americans of color witnessed the demonstration out of fear.

\section{Third Wave}

The Third Wave of the KKK contested civil rights advocacy in the 1950s and 1960s. ${ }^{38}$ The Klan challenged integration and African Americans' voting. The Ku Klux Klan's goals to maintain social and political segregation appeared in their words and deeds. The Klan's intents, targets, and methods are illustrated in the 1964 leaflet (Figure 12) distributed by the KKK in Mississippi.

Here are Twenty Reasons WHY you should, if qualified, join, aid and support the White Knights of the KU KLUX KLAN of Mississippi:

1. Because it is a Christian, fraternal and benevolent organization.

2. Because it is a democratic organization, governed by its members.

3. Because it is a democratic and just organization.

4. Because it is a working organization which not only talks but

38 Cunningham, Klansville, U.S.A.; Newton, The Ku Klux Klan. 


\section{ACTS.}

5. Because it is a very secret organization and no one will know that you are a member.

6. Because it is a legal organization and no one can be prosecuted for being a member.

7. Because it is a politically independent organization, and is not pledged to any political party.

8. Because it is a Pro-American organization that opposes any thing, person or organization that is Un-American.

9. Because it is an organization that is sworn to uphold the lawful Constitution of the USA.

10. Because it is composed of native-born, white, gentile and protestant American citizens who are sound of mind and of good moral character.

11. Because the goals of the KKK are the total segregation of the races and the total destruction of communism in all its forms.

12. Because the KKK has twice saved this nation from destruction as history clearly records.

13. Because there comes a time in the life of every man when he has to choose between the right to wrong side of life.

14. Because there are today many alien forces entering the United States of America bent upon its destruction.

15. Because it informs its members, and an informed citizen is a good citizen.

16. Because a Christian-like brotherhood among men must be revived in America.

17. Because one of the goals of the KKK is States' Rights and complete State Sovereignty.

18. Because neither the Conservatives nor the Liberals will save our nation, for patriots always save a nation.

19. Because it is clear now that if communism is to be defeated in America, it will be done in the South and primarily in Mississippi.

20. Because the KKK needs you today to help fight America's battles. The White Knights of the KU KLUX KLAN of Mississippi is a SECRET organization. The administration of our National Government is now under the actual control of atheists who are communists. As 
dedicated agents of Satan, they are absolutely determined to destroy Christian Civilization and all Christians. We have nothing to hide, but we must remain SECRET, for the protection of our lives and families. All of our members must meet a strict set of requirements:

- We are looking for ONLY: Sober, Intelligent, Courageous, Christian, American, White men.

- We do not accept Jews, because they reject Christ.

- We do not accept Catholics, because they follow the Roman dictator, the Pope.

- We do not accept Turks, Mongols, Orientals, Negroes, nor any other person whose native background of culture is different than White Christians.

The conflict has now become a Life and Death matter in America. The people of the non-American cultures CAN and COULD live under the White System, but they prefer to see it destroyed. The true American Whites, on the other hand, CAN NOT live under a Dictatorship of the Coloreds! This issue is clearly one of SELFDEFENSE or DEATH for White Americans. The White Americans have no choice but to defend our Constitutional Republic by every means at our command, because it is, LITERALLY, our LIFE. We will die without it.

If you are a Christian, White American Man who can understand the simple Truth of this Philosophy, you belong in the White Knights of the KU KLUX KLAN of Mississippi. We need your help right away. Get your Bible out and PRAY! You will hear from us.

Figure 12: From Mathisen, Critical Issues in American Religious History (2001). ${ }^{39}$

The text in this leaflet does not mince words about who is and who is not welcome in the Klan. This can be seen in reasons

39 Robert R. Mathisen, Critical Issues in American Religious History: A Reader (Waco, TX: Baylor University Press, 2001), 606-607. 
10 and 11, the Klan seeks White, Protestant males to protect segregation laws and thwart communism. The instructor can also prompt students to consider elements that repeat within various items. Students will likely identify camaraderie, secrecy, fear, and urgency in the document, as each aspect is repeatedly and explicitly emphasized. Other messages are implicit. The teacher might ask students to consider encoded messages in the source. Statements like, “...it [KKK] is a working organization which not only talks but ACTS" are ripe with meaning.

This leaflet reveals the political winds of change in 1964. The KKK likely felt defensive in 1964 because civil rights activists made significant gains. The Voting Rights Act of 1965 the following year dismantled Jim Crow segregation laws and de facto segregation laws throughout the United States. National sentiment, while difficult to quantify, abhorred the extremities and violence of racism embodied by the Klan. These realities caused the KKK to work in secrecy to prevent prosecution, which was possible on the federal level due to the Klan's dubious relationship with the Federal Bureau of Investigation. ${ }^{40}$

The Klan's Third Wave actions were usually, though certainly not always, done at night. The photograph in Figure 13 depicts several members of the Klan holding signs to support Barry Goldwater for president during the 1964 presidential campaign in San Francisco. The Klansmen's faces are concealed under the white hoods to protect their identities.

40 Newton, The FBI and the KKK: A Critical History. 


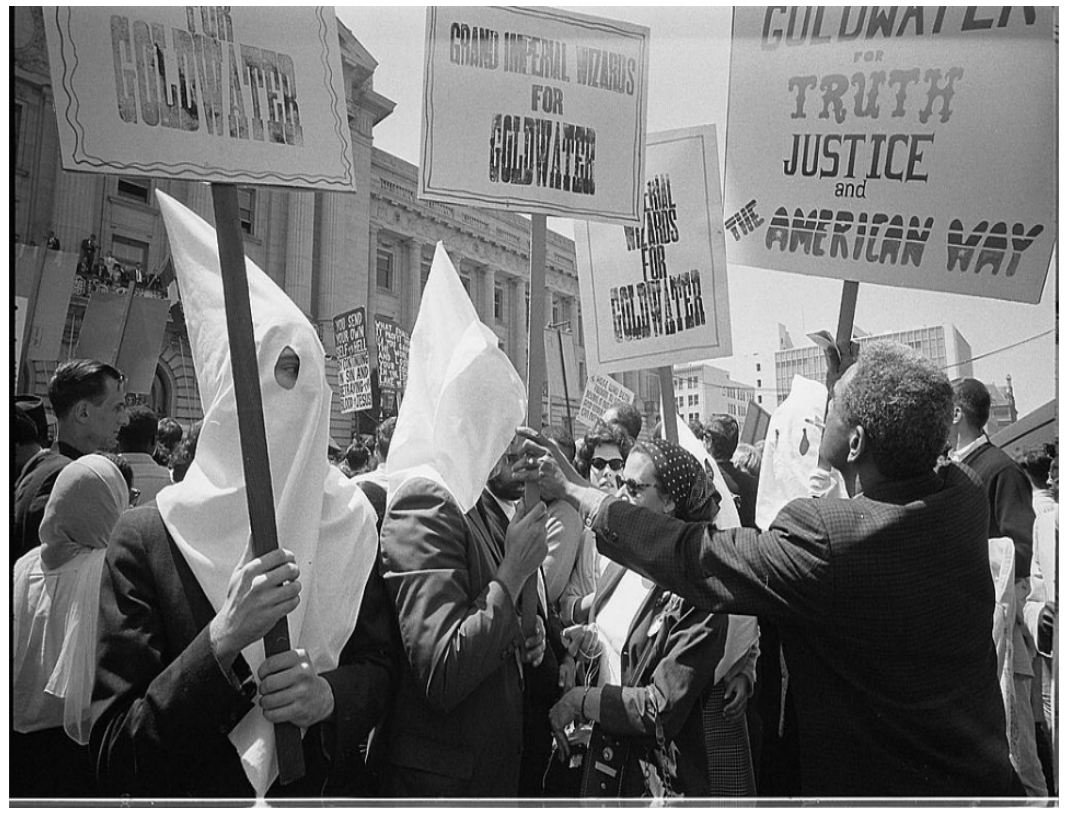

Figure 13: Ku Klux Klan Members Supporting Barry Goldwater's Campaign for the Presidential Nomination at the Republican National Convention, San Francisco, California, as an African American Man Pushes Signs Back, 1964. ${ }^{41}$

Teachers can spark students' analysis by eliciting their attention with a question like, "Which aspects of this photograph intrigue you or run counter to your understandings about the KKK?" Students may recognize the Klan members are demonstrating in front of the Republican National Convention. This reflects the protesting spirit of the 1960s as people and groups often occupied public spaces to convey messages to citizens and elected officials. ${ }^{42}$ The African American man resisting the KKK's presence is quite

41 Warren K. Leffler, photographer, Ku Klux Klan Members Supporting Barry Goldwater's Campaign for the Presidential Nomination at the Republican National Convention, San Francisco, California, as an African American Man Pushes Signs Back / WKL, 1964, photograph, Library of Congress, Washington, D.C., https:// www.loc.gov/item/2003673964/.

42 Alexander Bloom and Wini Breines, eds., Takin' It to the Streets, 4th ed. (New York, NY: Oxford University Press, 2015). 
noticeable. He actively confronted Klan members rallying in support of Goldwater. In previous documents, the Ku Klux Klan always appeared unopposed. The photograph likely also evokes questions that cannot be determined, such as the size of the counterdemonstration.

This photograph sparks students to explore the changing identity of the Ku Klux Klan. In its first two iterations, the KKK was clearly connected to the Democratic Party. As the Democratic Party moved more to the political left and Democratic presidents pushed for comprehensive civil rights legislation, the Klan-and the South as a whole-separated from its traditional political allegiances. ${ }^{43}$ Republican Barry Goldwater's emphasis on states' rights, a political victory when federal dominance is unattainable, garnered support throughout the Deep South. Goldwater lost the 1964 presidential election, but won much of the Deep South which became a Republican stronghold. ${ }^{44}$

Students evaluate and connect diverse primary and secondary sources. Their historical understandings become more complex as they incorporate nuances extracted from different documents. Students are now positioned to articulate newly-generated ideas through historical argumentation.

\section{Historical Argumentation}

Teachers and professors can spark and scaffold students' historical argumentation, as they did with history literacy and historical thinking. Students' writings in Table 1's analysis guideevidence of their emerging understandings - form the basis for historical argumentation. These remnants of history literacy and historical thinking can be shaped into a more robust edifice through peer and teacher review during historical argumentation.

\footnotetext{
43 Cunningham, Klansville, U.S.A.; Newton, The Ku Klux Klan; Rick Perlstein, Before the Storm: Barry Goldwater and the Unmaking of the American Consensus (New York, NY: Hill and Wang, 2002); Rick Perlstein, Nixonland: The Rise of a President and the Fracturing of America. (New York, NY: Simon \& Schuster, 2009). 44 Perlstein, Before the Storm; Perlstein, Nixonland.
} 
Students' writing should include the Klan's historical significance along with the roots, adaptations, and dominant figures of each particular iteration while originating from the examined material. Three possible prompts are provided as students address the question: How has hate appeared and changed in America?

\section{Table 2: Text-Based Writing Prompts}

1. Students write an evidentiary essay about the three waves of the KKK. They need to articulate the Klan's actions and goals while demonstrating how Klansmen violated African Americans' civil liberties. Evidence from diverse sources should be woven into their narratives to support their arguments. The audience is professional and informed.

2. Students create an annotated timeline detailing the three waves of the KKK. More than a sequence of events, annotated items must be thoroughly contextualized with appropriate citations substantiating claims. Annotated items include the intents, methods, targets, and how each changed with each iteration. Entries must be grounded in evidence extracted from primary and secondary sources. The audience is professional but uninformed.

3. Students develop original political cartoons, which combines students' criticality and creativity. ${ }^{45}$ Students first write a paragraph historicizing the Klan, its three waves, and its changing objectives, approaches, and intended victims. They build a concept map using ideas and evidence gleaned from primary and secondary sources. They then generate a list of concrete, visual images that substitute for abstract ideas on the concept map. With basic internet searches and common software, students produce original political cartoons. Finally, students should articulate, in writing, what messages they encoded and how they encoded the messages. Students' original

45 John Bickford, “Uncomplicated Technologies and Erstwhile Aids: How PowerPoint, the Internet, and Political Cartoons Can Elicit Engagement and Challenge Thinking in New Ways," The History Teacher 44, no. 1 (2010): 47-60; John Bickford, "Integrating Creative, Critical, and Historical Thinking through Close Reading, Document-Based Writing, and Original Political Cartooning," The Councilor: A Journal of the Social Studies 77, no. 1 (2016): 1-9. 
political cartooning and substantiated explanation critically and creatively communicate to all possible audiences.

These three writing activities allow students to draw on primary and secondary sources representing the KKK's three manifestations. Each option requires substantiation of claims and provides room for criticality, though one offers more creative options. Regardless of the selection, students articulate how the Klan's racist rhetoric and actions led to the violation of marginalized groups' civil liberties and was a looming threat in their daily lives. ${ }^{46}$

\section{Discussion}

We focused on teaching the three iterations of the Klan in the $19^{\text {th }}$ and $20^{\text {th }}$ centuries. There are additional tangential topics worthy of consideration. We offer high school teachers and professors four logical pathways for extension to help students consider the question: How has hate appeared and changed in America?

First, instructors might want to prompt deeper scrutiny of the Klan. A plethora of KKK-based primary sources are available on websites for the Library of Congress, ${ }^{47}$ National Archives, ${ }^{48}$ Harper's Magazine, ${ }^{49}$ and White Terror in USA. ${ }^{50}$ Simple searches reveal both text and visual primary sources connected to the three waves of the Klan. High school teachers and college professors can utilize the archives to find sources and stories connected to the KKK's three iterations. These sites have great potential for students to research and analyze different types of primary

\footnotetext{
46 Jason Endacott, "Reconsidering Affective Engagement in Historical Empathy," Theory and Research in Social Education 38, no. 1 (2012): 6-47.

47 https://www.loc.gov.

48 https://www.archives.gov.

49 https://harpers.org.

50 http://whitesupremacyhistory.timeline.com.
} 
sources connected to the Klan.

Second, teachers might consider a divergent inquiry into an aspect of American history in which the Ku Klux Klan was impactful, though indirectly so. Dr. Ossian Sweet's 1925 murder trial $^{51}$ and Hugo Black's Supreme Court nomination ${ }^{52}$ are two consequential moments in history in which the KKK's shadow loomed large. Sweet, an African American physician, purchased a home with his family in a Detroit neighborhood in which they were unwelcome. Hostile crowds of white men, many of whom were tied to the Klan, stoned and shot at Sweet's house. Nearly a dozen African American family members and close friends, huddling in terror, fought to protect themselves and their property. In doing so, they killed a white vigilante and were charged with murder. The Sweet Trials, as they were known, attracted national attention in part because of the involvement of prominent national organizations, such the National Association for the Advancement of Colored People and Ku Klux Klan, and outspoken figures, such as the aforementioned William Joseph Simmons and famed attorney, Clarence Darrow. President Franklin Roosevelt nominated Hugo Black, who was officially a KKK member for two years starting in 1923 and resigned in legible longhand on Klan stationery. The Ku Klux Klan, particularly the Birmingham Klan, continued to provide tangible support for Black who remained deliberately and misleadingly silent on the matter. While these historical anecdotes are meaningful tangents for students' inquiry, both center on the Klan's male membership.

Third, the KKK gained a level of legitimacy in Southern society by the role women played with the group. With Victorian and

\footnotetext{
51 Kevin Boyle, Arc of Justice: A Saga of Race, Civil Rights, and Murder in the Jazz Age (New York, NY: Henry Holt, 2004); Phyllis Vine, One Man's Castle: Clarence Darrow in Defense of the American Dream (New York, NY: Amistad, 2004). 52 Noah Feldman, Scorpions: The Battles and Triumphs of FDR's Great Supreme Court Justices (New York, NY: Twelve, 2010); Michael R. Williams, Stephen K. Shaw, and William Pederson, eds., Franklin D. Roosevelt and the Transformation of the Supreme Court (Armonk, NY: M.E. Sharpe, 2004).
} 
antebellum norms of conduct, women were seen as the protectors of virtue in Southern society. This role of White Southern women added validity and decency through organizations like the Daughters of the Confederacy. The Daughters of the Confederacy gained notoriety for strongly advocating for the erection of Confederate monuments despite the flailing economies in the South. ${ }^{53}$ The missions of the Ku Klux Klan and Daughters of the Confederacy coincided to preserve White hegemony in the South through honoring antebellum history and keeping the political, economic, and social status quo in Southern society.

Students may examine a Confederate monument that was erected through the fundraising efforts of the Daughters of Confederacy. One example is the monument from Waxahachie, Texas honoring the service of Confederate veterans (Figure 14). This memorial was created in 1912 by The Daughters of the Confederacy to honor Confederate veterans.

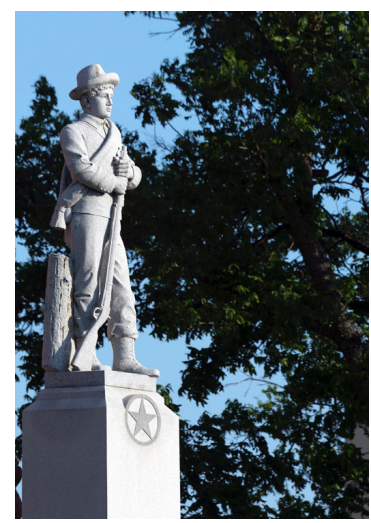

Figure 14: The text on the statue reads: "1861-1865, In honor of the dead and living of Ellis County who wore the gray, Banners may be furled but heroism lives forever." 54

53 David W. Blight, Race and Reunion: The Civil War in American Memory (Cambridge, MA: Harvard University Press, 2001); Karen L. Cox, Dixie’s Daughters: The United Daughters of the Confederacy and the Preservation of Confederate Culture (Gainesville, FL: University Press of Florida, 2003).

54 Carol M. Highsmith, The United Daughters of the Confederacy's Monument of a 
This Confederate monument can be explored by examining the inscription below this monument. The teacher can draw students to the inscription-"but heroism lives forever"-to spark discussion about the public memory of the Confederacy and Antebellum America. The teacher may use this inscription to discuss how the Daughters of the Confederacy sought to shape public perceptions. The approach to exploring Confederate monuments financially supported by the Daughters of the Confederacy can be replicated with other Confederate monuments throughout the South, which often misrepresent history for dubious reasons. ${ }^{55}$ The teacher may draw upon excerpts from Cynthia Mills and Pamela Simpson's Monuments to the Lost Cause: Women, Art, and the Landscapes of Southern Memory and Caroline Janney's Burying the Dead but Not the Past: Ladies' Memorial Associations and the Lost Cause. ${ }^{56}$ Meaningful discussions will emerge about how individuals and groups should and should not be honored, not simply remembered or studied.

Finally, the last decade has seen many meaningful steps toward the inclusion and acceptance of diversity in U.S. society. However, an undercurrent of resistance has been present in U.S. society. The one event that best embodies this resistance to diversity is the Unite the Right rally at Charlottesville in August of 2017. ${ }^{57}$ At this event, different right-wing groups met to protest

Rebel Soldier was Dedicated in Front of the Ellis County Courthouse in Waxahachie, Texas, and Still Stands There. Ellis County Texas, United States, Waxahachie, 5-10-2014, 2014, photograph, Library of Congress, Washington, D.C., https:// www.loc.gov/item/2014632593/.

55 James W. Loewen, Lies Across America: What our Historic Sites Got Wrong (New York, NY: Touchstone, 1999).

56 Cynthia Mills and Pamela H. Simpson, eds., Monuments to the Lost Cause: Women, Art, and the Landscapes of Southern Memory (Knoxville, TN: The University of Tennessee Press, 2003); Caroline E. Janney, Burying the Dead but Not the Past: Ladies' Memorial Associations and the Lost Cause (Chapel Hill, NC: The University of North Carolina Press, 2012).

57 Meg Wagner, "Blood and Soil," CNN, https://www.cnn.com/2017/08/12/us/ 
the removal of the Robert E. Lee monument in Charlottesville's Emancipation Park. These right-wing groups were met with protestors and the resulting clashes led to three deaths, one counter-protester and two police officers.

The teacher may have students explore multiple comments from Donald Trump, President of the United States, and David Duke, former Grand Wizard of the KKK. The comments, which originate from an interview and extend into Twitter, are about the Unite the Right Rally. The remarks, which occurred both before and after the Charlottesville violence, are provided below (Figure 15).

David Duke, speaking on the morning of August 12, 2017 on CNN about the Unite the Right Rally in Charlottesville, Va. prior to the afternoon's violent clashes between White Supremacy advocates and anti-racist protestors: "This represents a turning point for the people of this country. We are determined to take our country back, we're going to fulfill the promises of Donald Trump, and that's what we believed in, that's why we voted for Donald Trump, because he said he's going to take our country back and that's what we gotta do."

Donald Trump, in a tweet at noon on August 12, 2017: "We ALL must be united \& condemn all that hate stands for. There is no place for this kind of violence in America. Lets [sic] come together as one!"

Duke, in separate retweets around 1pm on August 12, 2017: "So, after decades of White Americans being targeted for discriminated \& antiWhite hatred, we come together as a people, and you attack us? ... I would recommend you take a good look in the mirror \& remember it was White Americans who put you in the presidency, not radical leftists."

Figure 15: Statements by President Donald Trump and David Duke, August $2017 .^{58}$

charlottesville-unite-the-right-rally/index.html.

58 Julia Manchester, "David Duke, Charlottesville Protests about 'Fulfilling 
The above sources enable students to see how the KKK associates itself now with the Republican Party as opposed to the Democratic Party, which it was connected to through the three manifestations of the Klan. Students can research why the KKK aligns itself to the Republican Party and Donald Trump's message and how they feel insulted by Trump's tweet. This inquiry allows students to see how the political message of Goldwater that started the Klan's political migration in the 1960s has resulted in members of the KKK identifying with the message of the Republican Party and its current standard-bearer, President Donald Trump. The 2017 Charlottesville tragedy coupled with race targeted violence over the last couple years such as the Charleston church shooting, where a White supremacist murdered nine African Americans, may lead future historians to claim that during the Obama and Trump presidencies that a fourth manifestation of the KKK appeared. Teachers can return students to the central questionHow has hate appeared and changed in America?-to consider their role as citizens and place history's emergent reverberations in their proper historical context. Americans must continue to use evidence and engage in historical and contemporary inquiries as citizens to consider how hate appears and changes in America.

Promises of Donald Trump,"' The Hill (blog), August 12, 2017, https://thehill. com/blogs/blog-briefing-room/news/346326-david-duke-charlottesvilleprotests-about-fulfilling-promises. 